\title{
Apropiación de elementos y símbolos de legitimidad entre la nobleza indígena. El caso del cacicazgo tlatelolca
}

\author{
María Castañeda de la Paz
}

Universidad Nacional Autónoma de México

La documentación del cacicazgo tlatelolca es abundante pero problemática, debido a la incongruencia de mucha de su información. No realizar un minucioso análisis filológico de las fuentes nos llevaría a errar en nuestras interpretaciones históricas. El presente artículo es por tanto una muestra del fascinante mundo de las reelaboraciones históricas, donde no están ausentes los documentos falsos y las apropiaciones ilegítimas de símbolos y hazañas históricas. Para ello se ha tomado como caso de estudio al cacique tlatelolca, don Diego de Mendoza (1549-1562).

Palabras Clave: Tlatelolco, Colonia, fuentes históricas, Filología.

The documentation concerning the cacicazgo of Tlatelolco is abundant but problematic due to the incongrous nature of much of the information. It is necessary to apply a meticulous philological analysis of the sources in order to avoid errors in our historical interpretations. As such, the present article is a sample of the fascinating world of historical elaboration which includes false documents and illegitimate appropiation of symbols and historical feats. I will show this through a case study of the Tlatelolco cacique Don Diego de Mendoza (1549-1562).

KeYwords: Tlatelolco, Colonial period, historical sources, Philology.

\section{Introducción}

A lo largo del siglo XVIII, numerosas familias del centro de México comenzaron a producir abundantes documentos. A través de ellos demostraban su condición de caciques y principales con el objetivo de obtener ciertas prerrogativas reales. Lo hacían remitiéndose a un antepasado del siglo XVI, generalmente notable por su noble ascendencia prehispánica o por su destacado papel en la conquista española. Ese fue el caso de los principales de Tlaxcala, Tizatlan, Tlacopan, Tula o Almoloya, por sólo mencionar algunos ejemplos. ${ }^{1}$

1 Para un buen ejemplo de estas familias cacicales véase el libro de Fernández de Recas, Guillermo: Cacicazgos y nobiliario indígena de la Nueva España, Universidad Nacional Autónoma de México, México, 1961. 
Para este trabajo he tomado como caso de estudio a una familia de caciques tlatelolcas que a lo largo del siglo XVIII se decían descendientes de don Diego de Mendoza Austria Moctezuma. Un personaje que poseía los apellidos más ilustres de una época, puesto que el Mendoza le venía por el virrey don Antonio de Mendoza, miembro de una de las familias más nobles de España, muy cercana al emperador Carlos V; el Austria por el apellido del monarca español y su familia (los Austrias o Habsburgos); y el Moctezuma por el emperador mexicano, Moctezuma Xocoyotzin o Moctezuma II.

La información que esta familia nos ha legado es bastante abundante y está constituida por numerosos documentos alfabéticos en español; algunos - muy pocos - en nahuatl; una serie de pinturas-retratos; escudos de armas; y hasta un códice techialoyan. ${ }^{2}$ De muchos de esos documentos hay también copias en los distintos legajos, muestra de que muchas familias se afanaron por reunir papeles que testimoniaran ser descendientes del cacique tlatelolca.

El presente artículo tiene por tanto la finalidad de analizar la información contenida en estas fuentes. Se hará a través de un análisis filológico con la intención de demostrar que para trabajar con la historia de un cacicazgo colonial de larga duración, no podemos tomarnos a la ligera, y sin una mirada crítica, el contenido de su información. Muchas de estas fuentes esconden un oscuro mundo de elaboraciones y reelaboraciones históricas que pueden estar motivadas por infinidad de causas: alteración de la información transmitida de forma oral, olvido de ciertos datos, necesidades del momento, etc. Todo ello sin olvidar la posible existencia de métodos bastante dudosos.

El artículo amerita, pues, que se comience hablando de la historia más antigua de Tlatelolco. Es necesario hacerlo para entender la información que luego vamos a ver registrada a lo largo de todo el período colonial, en torno a la figura de don Diego de Mendoza.

\section{Tlatelolco. Un breve recorrido por su historia más antigua}

Los tlatelolcas fundaron su ciudad, Tlatelolco, a escasos kilómetros de Tenochtitlan, pocos años después de la fundación de ésta en el 1325 d.C.

2 Los techialoyan son un género pictográfico con un estilo pictórico y una escritura en nahuatl con rasgos muy particulares que se datan en la segunda mitad del siglo XVII y la primera mitad del XVIII. Véase Noguez, Xavier: Códice Techialoyan García Granados, edición facsimilar, comentarios de Xavier Noguez y Rosaura Hernández, Gobierno del Estado de México, El Colegio Mexiquense, México, 1992, págs. 8 y 10. 
Pero mientras la casa real tenochca estuvo principalmente vinculada con las casas reales de Culhuacan y Tula; la de Tlatelolco lo estuvo con la casa real de Azcapotzalco, capital del pueblo tepaneca, cuyo soberano de entonces era el legendario Tezozomoc.

Hasta 1428, tenochcas y tlatelolcas fueron tributarios de los tepanecas de Azcapotzalco, si bien a raíz de esa fecha, y poco más de un siglo después de la fundación de Tenochtitlan y Tlatelolco, la situación política en el centro de México dio un repentino giro. ${ }^{3}$ Itzcoatl — cuarto tlatoani (señor gobernante) tenochca- derrotó al soberano Maxtla (hijo de Tezozomoc) y acabó con la supremacía tepaneca. Esta situación debió afectar muy directamente a Tlatelolco porque, como se ha dicho, su casa real estaba emparentada con la de Azcapotzalco. Pero el golpe más duro estaba por venir. En 1473, Axayacatl — sexto tlatoani tenochca- tomó Tlatelolco y venció a su soberano Moquihuix, poniendo fin al tlatocayotl (señorío) de esta parte de la ciudad. A partir de entonces, esta ciudad quedó bajo el gobierno de jefes militares de Tenochtitlan y su casa real relegada a un segundo plano, siendo difícil saber qué fue de ella. Lo más probable es que sus miembros se mantuviesen ocupando cargos militares junto con los militares tenochcas. ${ }^{4}$

Sea como fuere, esa fue la situación socio-política que los españoles encontraron al llegar al islote de México, donde se hallaban ubicados ambos pueblos o altepetl. ${ }^{5}$ Es decir, que independientemente del gobierno de esos militares, Tlatelolco se encontraba bajo la autoridad de Moctezuma II. Por otro lado, parece que fue esta coyuntura histórica (la llegada española) la que permitió que Tlatelolco recuperara su antiguo estatus perdido.

El período de conquista es confuso y oscuro, ${ }^{6}$ siendo Cuauhtemoc una figura clave del momento. Era hijo de padre tenochca (Ahuizotl) y madre

3 Sobre todo este asunto véase Garduño, Ana: Conflictos y alianzas entre Tlatelolco y Tenochtitlan. Siglos XII a XV, Serie Historia, Instituto Nacional de Antropología e Historia, México, 1997, pág. 92 y Castañeda de la Paz, María: "Itzcoatl y los instrumentos del poder", Estudios de Cultura Nahuatl, núm. 36, 2005, págs. 115-147; "De Aztlan a Tenochtitlan. Historia de una peregrinación”, Latin American Indian Literatures Journal, vol. 18, n. o 2, Texas, otoño, 2002, págs. 163-212.

4 Véase Barlow, Robert H.: Tlatelolco. Fuentes e Historia, vol. II, ed. Jesús Monjarás-Ruiz, Elena Limón y María de la Cruz Paillés H., Instituto Nacional de Antropología e Historia, Universidad de las Américas, México, 1989, págs. 127-130.

5 Para la definición de altepetl y la evolución del término véase Lockhart, James: Los nahuas después de la conquista. Historia social y cultural de la población indígena del México Central, siglos XVI-XVIII, Fondo de Cultura Económica, México, 1999, cap. II, págs. 29-36 y 85-88.

6 Hasta el momento, sólo Barlow ha tratado el tema con cierta profundidad. Véase Barlow: Tlatelolco. Fuentes e..., págs. 127-130. 
tlatelolca (Tlayacapatzin), pero también sobrino de Moctezuma. ${ }^{7}$ Sin duda, su doble ascendencia fue lo que le permitió contar con el apoyo de ambos pueblos en su lucha contra los españoles. Pero todos sabemos que Cuauhtemoc fue derrotado. A partir de entonces es importante conocer que fue el propio Cortés el que restituyó la casa real tlatelolca al nombrar como gobernante a un principal llamado Juan Ahuelitoc. ${ }^{8}$ Aunque su nombre no nos es muy familiar, don Juan Ahuelitoc no era un completo desconocido en el México de entonces. De la poca información que proporcionan las fuentes se sabe que era hijo de Temillotzin, un principal que tuvo un destacado y valiente papel junto a Cuauhtemoc en la defensa de Tlatelolco. ${ }^{9}$ Por tanto, uno de esos miembros de la casa real tlatelolca, a la sombra de la Tenochtitlan de entonces. De esta manera, mientras Cuauhtemoc quedó como señor de Tenochtitlan, Ahuelitoc quedó como señor de Tlatelolco, dividiéndose el altepetl, tal como había estado antes de 1473.

Desde ese momento, y gradualmente, los gobernantes dejarían de llamarse tlatoque (sing. tlatoani) y pasarían a denominarse gobernadores. Será muchos años después cuando pueda constatarse la llegada de don Diego de Mendoza al gobierno de Tlatelolco. Este personaje entrará en la escena histórica entre 1549 y 1562.

\section{Problemas en torno a la figura de Don Diego de Mendoza Austria Moctezuma Huitznahuatlailotlac Imauhyantzin}

Entre 1549 y 1560 , don Diego de Mendoza aparece en las fuentes como cacique-gobernador de Tlatelolco. En realidad lo fue hasta 1562, pero los dos últimos años de su vida los pasó en la cárcel. Se realizará a continuación un esbozo de quién fue este personaje histórico tan importante para ciertas familias tlatelolcas.

7 Torquemada, fray Juan de: Monarquía Indiana, Universidad Nacional Autónoma de México, México, 1975, Lib. IV, cap. LXXX, pág. 248; Ixtlilxochitl, Fernando de Alva: Obras Históricas, 2 vols., Universidad Nacional Autónoma de México, México, 1975, vol. II, cap. LXX, pág. 177.

8 Torquemada: Monarquía Indiana..., lib. IV, cap. CII, pág. 311. No obstante, Sahagún nos dirá que el primer gobernador fue don Pedro Temilo — padre de don Juan Ahuelitoc_ y tras él, Martín Ecatl. Véase Sahagún, Bernardino de: Historia General de las cosas de la Nueva España, edición de Juan Carlos Temprano, 2 vols., Historia 16, Madrid, 1990, vol. 2, lib. 8, cap. II, pág. 561.

9 Sobre esa relación parental véanse los Anales de Tlatelolco, CONACULTA, México, 2004 págs. 36, 37, 39, 117 y 119. Sobre su papel junto a Cuauhtemoc se puede consultar Torquemada: Monarquía Indiana..., lib. IV, cap. XCII, pág. 283. 
Podría comenzar señalando que, curiosamente, es sólo en el siglo XVI cuando don Diego lleva junto a su nombre cristiano sus otros nombres indígenas. ${ }^{10}$ Es decir, que no será hasta el siglo XVIII cuando aparezca en los documentos como don Diego de Mendoza Austria Moctezuma, aunque el apellido Mendoza se usó indistintamente en todos los siglos. ${ }^{11}$ En relación con este asunto es lógico imaginar que Tezozomoc, que escribió su Crónica Mexicayotl a finales del siglo XVI, conociera a don Diego de Mendoza. No sólo porque los dos pertenecían a la nobleza mexica sino porque, según algunas fuentes, ambos debían ser primos-hermanos. ${ }^{12}$ Empero, si esto fuera cierto, cómo explicar que Tezozomoc olvidara mencionar aquella noble ascendencia y simplemente dijera que don Diego era hijo de Zayoltzin, "principe de ese señorío", en alusión al señorío de Tlatelolco. ${ }^{13}$ Sin embargo, al contrario de los cronistas tempranos, la documentación del XVIII no dejará de reiterar que Cuauhtemoc fue su progenitor. Con la madre de don Diego sucede algo similar. Resulta nuevamente extraño que Tezozomoc la hubiera pasado por alto, mientras que los pocos cronistas o conquistadores del siglo XVI que hablan de una posible hija de Moctezuma casada con Cuauhtemoc no puedan precisar si ésta era doña Isabel u

10 Con el nombre de Huitznahuatlailotlac aparece don Diego en Sahagún: Historia General de.., pág. 561. Con el nombre de Imauhyantzin en la Séptima Relación de Chimalpahin, Cuauhtlehuanitzin, Domingo: Las ocho relaciones y el Memorial de Colhuacan, 3 vols., paleografía y traducción de Rafael Tena, Cien de México, Mexico, 1998, pág. 215 y en el fol. 8v del Códice Cozcatzin, estudio y paleografía de Ana Rita Valero de García Lascuráin, paleografía y traducción de los textos nahuas de Rafael Tena, Instituto Nacional de Antropología e Historia, Benemérita Universidad Autónoma de Puebla, México, 1994. En este último documento, y por corrupción, leemos Mauhanchi.

11 Este aspecto ya había sido observado por López Mora, Rebeca: "El cacicazgo de Diego de Mendoza Austria y Moctezuma: un linaje bajo sospecha”, El cacicazgo en Nueva España y Filipinas, Margarita Menegus y Rodolfo Aguirre (coords.), Plaza y Valdés, Universidad Nacional Autónoma de México, México, 2005, págs. 214-215. Sin embargo, la autora creyó que el Moctezuma se omitía en el siglo XVI porque en el nuevo tiempo era mejor ocultar que su supuesto padre — Cuauhtemoc- estaba casado con dos medias hermanas, hijas de Moctezuma. Además, porque el hecho de utilizar el Austria Moctezuma le hubiera conferido a don Diego mayor estatus que a otros caciques del centro de México. Sin embargo, en ninguna fuente se menciona que Cuauhtemoc estuviera casado con dos hijas de Moctezuma y a saber si se casó con alguna, como luego se discutirá. Tampoco se explica qué problema hubieran podido tener los cronistas al hablar de un señor de mayor estatus que otro. Pero este asunto del apellido y la ascendencia de don Diego será comentado más adelante.

12 Tezozomoc dice ser hijo de doña Francisca de Moctezuma, y por tanto, nieto de Moctezuma II. Véase Tezozomoc, Hernando de Alvarado: Crónica Mexicayotl, Universidad Nacional Autónoma de México, México, 1992, págs. 157-158. Como a continuación se verá, don Diego también lo es porque su padre se casó con otra hija de Moctezuma.

13 Tezozomoc: Crónica Mexicayotl..., pág. 172. La cuestión es que ni Chimalpahin ni Sahagún lo citan como un Mendoza Moctezuma. 
otra. ${ }^{14}$ Un asunto que contrasta con las fuentes del siglo XVIII, las cuales señalan con toda claridad a doña María (Moctezuma) Cortés Xochimatzatzin como esposa de Cuauhtemoc. Sabemos que Moctezuma II tuvo una hija llamada María, pero según Tezozomoc murió joven. ${ }^{15}$ Sea como fuere, varios documentos tardíos explican toda esta ascendencia y no olvidan mencionar a doña María. Quizás uno de los más completos es el llamado Árbol de la Cesárea Regia Prosapia de 1741 guardado en el Archivo General de la Nación:

[1v] Arbol de la Sesarea Rexia Prosapia del Emperador Moctesu [sic] Ultimo deste Ymperio Mexicano. Padre Lexitimo de [En el margen: hija] D[oñ]a Maria Motezuma Cortez Suchimatzatzin muger lexitima de D[o]n Fernando Quautemoc Huitzilihuit, Sobrino del emperador Moctezuma y su subsesor padre de [En el margen: Nieto] $\mathrm{D}[\mathrm{o}] \mathrm{n}$ Diego de mendosa el viexo apellidado Austria [...]. ${ }^{16}$

Otro de esos documentos es el anverso y reverso del Códice Techialoyan García Granados (fig. 1). El único con una ilustración de doña María. En el anverso, ella está detrás de Cuauhtemoc y unida a don Diego por una línea roja. Se la representa con unas enaguas o huipil de ese mismo color, en cuyo escote - y como componente de su apellidose dibuja la imagen de Moctezuma. Otro de sus apellidos —el de Xochimatzatzin-, lo proporciona un glifo del que sólo se adivina la hoja de una flor (xochi-tl). En el reverso vemos a esta misma mujer, idénticamente vestida y en la misma posición con respecto a don Diego. Aquí no hay duda de su glifo onomástico: una flor roja con su tallo y una hoja. ${ }^{17}$

En relación con este nombre me llamó la atención que Tezozomoc mencionara a una mujer llamada doña María Xochimatzatzin. El problema es que ésta era hija de Moctezuma Ilhuicamina y no de Moctezuma II o Moctezuma Xocoyotzin. Aún así, debió de ser una señora de gran importancia para la historia como para que Tezozomoc la recordara a finales del

14 García Granados, Rafael: Diccionario Biográfico de Historia Antigua de Méjico, 3 vols. Instituto de Historia, México, 1953, vol. 3, págs. 148-150. En este punto hay que señalar además que es muy raro que la propia doña Isabel no mencionara a Cuauhtemoc entre los maridos que tuvo.

15 Tezozomoc: Crónica Mexicayotl..., págs. 155-156.

16 Archivo General de la Nación (en adelante AGN), Tierras, 1593, n. ${ }^{\circ}$ 1, f. 1v.

17 El problema radica en las glosas puesto que el glosista ya no supo que se trataba de la misma mujer que en el anverso del documento. Ahora la nombra "doña Eusebia Bautista de [roto]". Este tipo de errores los cometerá en más de una ocasión. 


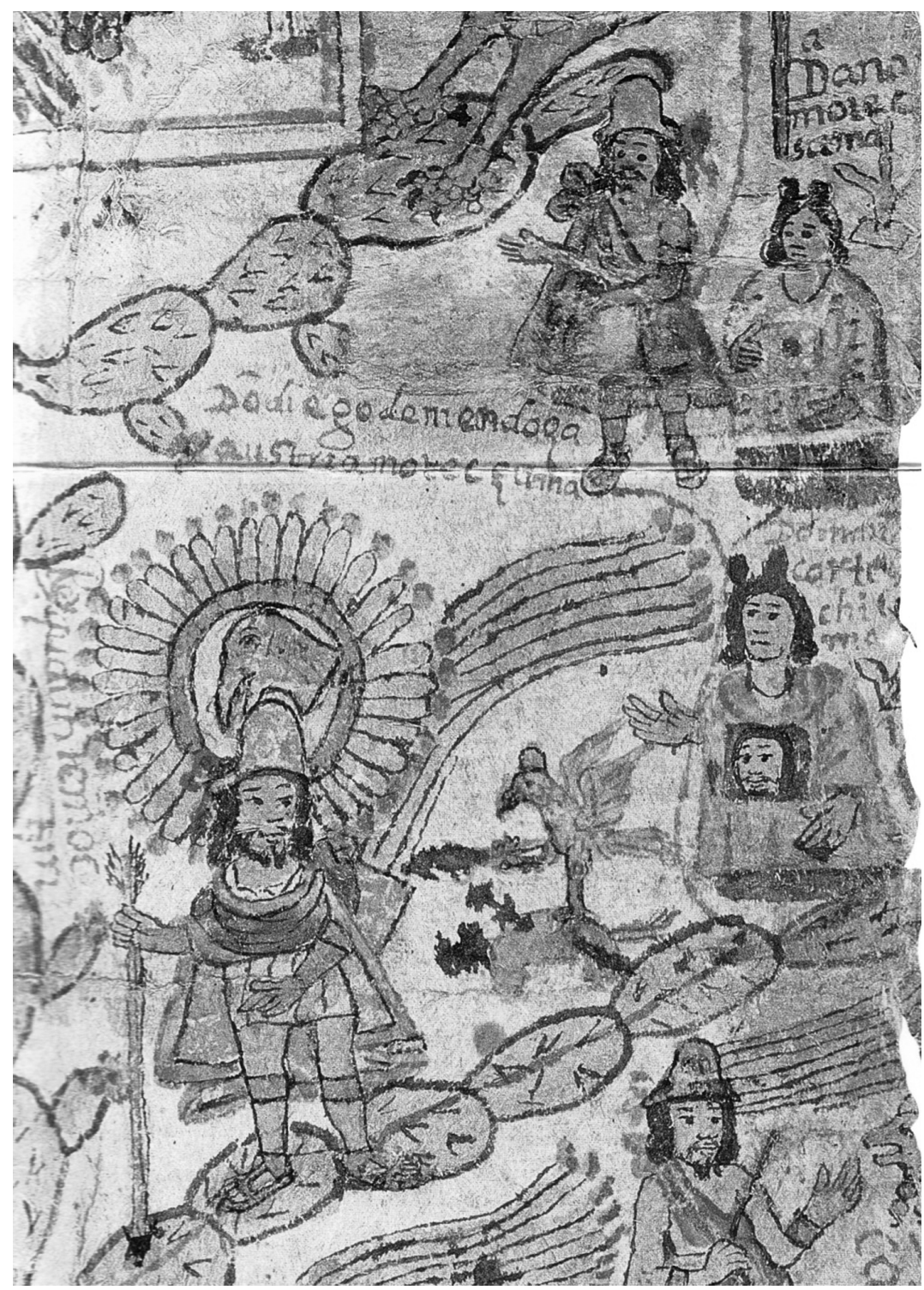

Fig. 1: Cuauhtemoc, doña María Xochimatzatzin y don Diego de Mendoza. Códice Techialoyan García Granados (edición facsimilar, comentarios de Xavier Noguez y Rosaura Hernández, Gobierno del Estado de México/El Colegio Mexiquense, México, 1992). 
siglo XVI y le dedicara algunas líneas a ciertos aspectos de su vida. ${ }^{18}$ Ahora bien, lo que es importante señalar aquí es que la existencia de diferentes personas con el mismo nombre y relaciones de parentesco idénticas no es fruto de la casualidad. Una explicación posible y verosímil es que el paso del tiempo diera lugar a un proceso de "estructuración" en la memoria histórica de Tlatelolco. Este proceso de la fusión de dos o más personas análogas es un aspecto muy bien conocido en la tradición oral, que en este caso se manifiesta cuando los dos Moctezumas se convirtieron en uno y, consecuentemente, sus hijas también. ${ }^{19}$ Así, la doña María Xochimatzatzin, hija de Moctezuma Ilhuicamina de la que nos hablaba Tezozomoc, se convirtió en doña María Xochimatzatzin, hija de Moctezuma Xocoyotzin.

Ya hemos visto que las fuentes del siglo XVI no dicen si doña María se casó con Cuauhtemoc o no, pero no hay que olvidar que el período colonial temprano está recogido de manera relativamente pobre en las fuentes documentales. Si así fue, está más allá de cualquier duda que fue una importante alianza entre dos señoríos y Don Diego de Mendoza Austria Moctezuma pasó a ser un atractivo personaje al que estar vinculado.

Acerca de la vida de don Diego poco más conocemos. Existe un documento pictográfico — el Códice de Tlatelolco — que nos habla de su participación en la conquista del norte de la Nueva España, emprendida por el virrey Mendoza. No puedo asegurar si don Diego lo hizo de manera activa - participando él mismo-, o lo hizo enviando tropas. Sea como fuere, datos de esta participación quedan reflejados en el citado códice mediante una escena en la que ciertos guerreros indígenas regresan junto con algunos españoles de las conquistas de Culiacán y Nochistlán..$^{20}$ Desde el punto de vista del documento, el papel de los tlatelolcas fue fundamental. Por eso, éstos aparecen vestidos como grandes guerreros y sus proporciones

18 Tezozomoc: Crónica Mexicayotl..., pág. 111. En el texto aparece como Macaxochictzin (o sea, Maçaxochtzin o Matzaxochtzin) y con el nombre en orden invertido. Debe ser Xochi-matza-tzin. Esta mujer fue a Tepexi de la Seda (Puebla) a casarse con un señor local para iniciar un nuevo señorío. Sobre esta señora, pero con el nombre Mazaxochitzin, véase Michel R. Oudijk y Matthew Restall: $L a$ conquista de Mesoamérica: El caso de don Gonzalo Mazatzin Moctezuma, Secretaría de Cultura del Gobierno del Estado de Puebla, Puebla (en prensa).

19 Vansina, Jan: Oral Tradition as History, University of Wisconsin, Madison, 1985, pág. 21.

20 Según Perla Valle la escena en el documento representa dos campañas distintas. Por un lado la poco exitosa entrada organizada por el entonces gobernador de la Nueva Galicia, Vázquez de Coronado (asociado al cerro de Culiacan), en la que, según el Padre Tello, participaron guerreros tlatelolcas. Por el otro lado, la expedición posterior dirigida por el virrey don Antonio de Mendoza (asociada al cerro de Nochistlan) con el objetivo de sofocar posteriores sublevaciones. Véase El Códice de Tlatelolco, edición facsimilar, estudio preliminar de Perla Valle, Instituto Nacional de Antropología e Historia y Benemérita Universidad Autónoma de Puebla, México, 2006, págs. 59-60. 
con respecto a la de los conquistadores españoles hacen que estos últimos pasen a un muy segundo plano. A continuación aparece el gobernador como señor de Tlatelolco, sedente sobre el glifo de su pueblo (fig. 2): un montículo arenoso (xalli) o terregoso (tlalli). ${ }^{21}$ Está vestido a la manera indígena y en una silla de tipo español. Al estar pintado de una forma tan cuidada y en un tamaño mayor al de otros personajes, se piensa que el documento fue probablemente mandado pintar por orden suya. Respecto a la participación indígena en la conquista española hay que mencionar que el rey premió a sus conquistadores — no sólo a los españoles - con un escudo de armas. ${ }^{22}$ Esto explicaría que entre la documentación del siglo XVI exista una cédula real concedida por Felipe II a don Diego de Mendoza, otorgándole un blasón como compensación a sus servicios en la conquista de los territorios del norte de la Nueva España. Esta cédula, por su problemático carácter, será comentada en el siguiente apartado.

Sobre el final de su vida sólo me resta decir que don Diego se vio envuelto en un problema de tierras. El fol. 51v del Códice Aubin dice que "El 12 de agosto [de 1559] empezó su trabajo don Esteban de Guzmán, juez. Vino a arreglar lo de las tierras del calpulli’. ${ }^{23}$ Sea como fuere, pare-

21 Torquemada (Monarquía... 1975, lib. 3, cap. XXIV, págs. 294-295) señala que el nombre original del sitio fue Xaltelolco porque allí encontraron un montículo de arena ( $\mathrm{xal}$-li), aunque con el tiempo la ciudad fue creciendo y se fueron cegando las aguas con piedras y tierra. Pasó entonces a denominarse Tlatelolco que se traduciría como "En el Montículo de Tierra (tlatel-li) Redondo (ol-oltic)".

22 Acerca del motivo de la participación indígena en la empresa de conquista y su grado de implicación véase AA. VV.: Indian Conquistadors, Matthew Restall y Michel R. Oudijk (eds.), Oklahoma University Press, Norman, 2007. Sobre la participación de los quauhquecholteca en la conquista de Guatemala y el papel tan importante que desempeñaron los diferentes grupos indígenas, entre ellos los tlaxcalteca, consúltese Asselberg, Florine: The Lienzo de Quauhquechollan: a Nahua vision of the conquest of Guatemala, CNWS, Países Bajos, 2004, págs. 91-95. Acerca de la participación de distintos pueblos de la cuenca de México en las diversas campañas y la consiguiente solicitud y concesión de un escudo de armas, véase Luque Talaván, Miguel y Castañeda de la Paz, María: "Escudos tlaxcaltecas. Iconografía prehispánica y europea”, Arqueología Mexicana, vol. XIV, núm. 82, noviembrediciembre de 2006, págs. 68-73; Castañeda de la Paz, María, y Luque Talaván, Miguel: “Conquistadores o conquistados? Análisis pictográfico de los escudos concedidos al pueblo tepaneca por la Corona española", Actas del VI Coloquio Paul Kirchhoff, Universidad Nacional Autónoma de México, México (en prensa) y Castañeda de la Paz, María: "Central Mexican Indigenous Coats of Arms and the Conquest of Mesoamerica". En Ethnohistory (en prensa).

23 Códice Aubin: Geschichte der Azteken. Der Codex Aubin und verwandte Dokumente, aztekischer Text Übersetzt und erläutert von Walter Lehmann und Gerdt Kutscher, Berlin, Gebr. Mann Verlag, 1981. Los Anales de Juan Bautista nos dicen que fue el 28 de octubre de 1560, día de la fiesta de San Simón. Véase Anales de Juan Bautista: ¿Cómo te confundes? ¿Acaso no somos conquistados?, paleografía, traducción y estudio de Luis Reyes García, Biblioteca Lorenzo Boturini/ Insigne y Nacional Basílica de Guadalupe/ CIESAS, México, 2001, párr. 3. En su Séptima Relación, Chimalpahin (Ocho Relaciones... pág. 213) la retrasa un poco más, al 4 de noviembre de ese mismo año. Lo importante es que son varias las fuentes que corroboran la llegada de un juez a Tlatelolco. Véase también Barlow: Tlatelolco. Fuentes e..., pág. 151. 


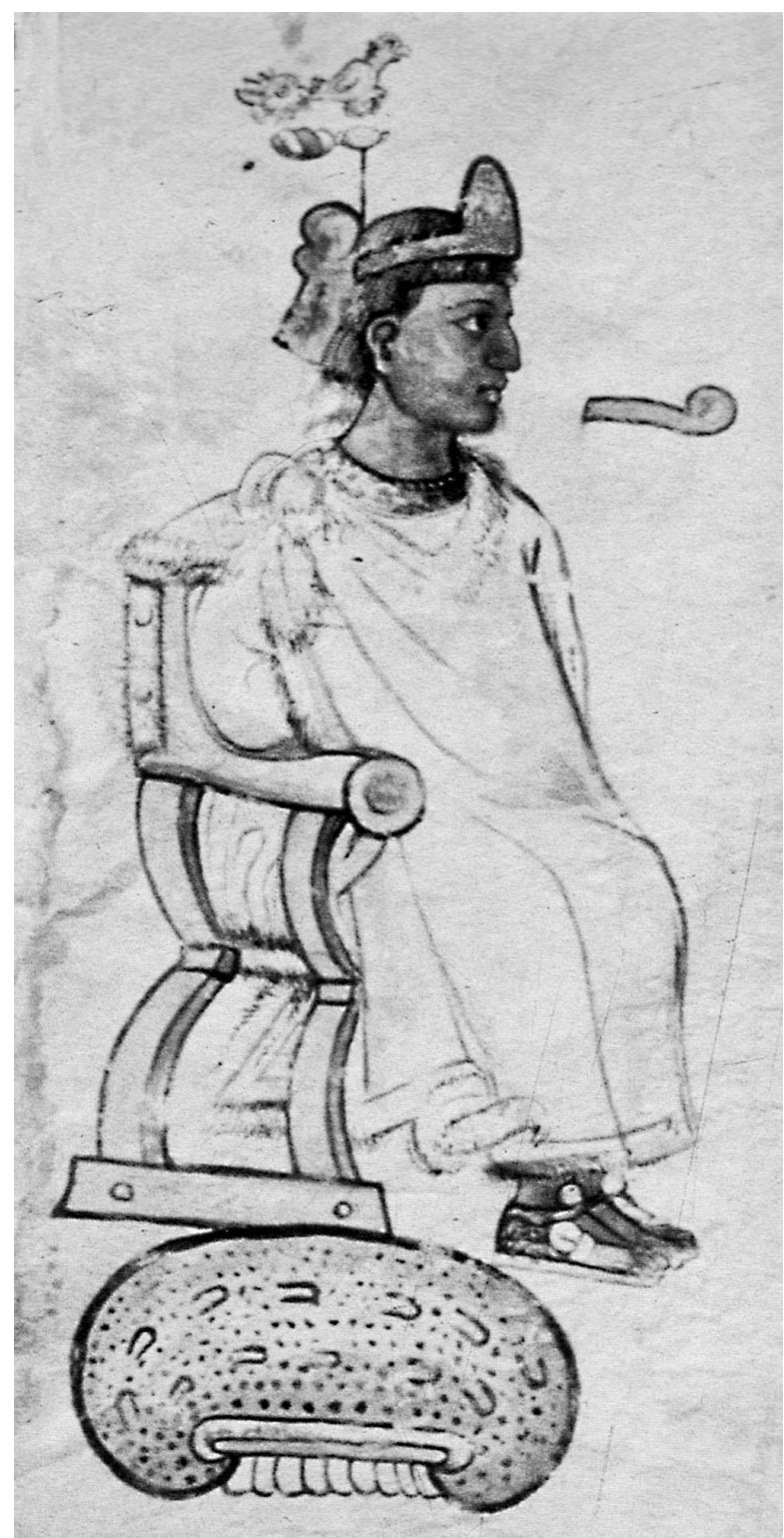

Fig. 2: Don Diego de Mendoza. Códice de Tlatelolco (edición facsimilar, estudio preliminar de Perla Valle, Instituto Nacional de Antropología e Historia y Benemérita Universidad Autónoma de Puebla, México, 2006). 
ce que por estos delitos de tierras el gobernador de Tlatelolco ingresó en prisión, muriendo a los dos años del juicio de residencia al que fue sometido. Chimalpahin precisa que esto tuvo lugar el 20 de diciembre de 1562. ${ }^{24}$

Don Diego dejó tres hijos, Melchor, Gaspar y Baltasar, pero ninguno lo sucedió directamente en el cargo. Al contrario, hubo un vacío de poder hasta 1567, fecha en la que alcanza el cargo de juez-gobernador don Miguel García. Poco o nada se sabe de él, salvo que estuvo también largo tiempo gobernando. Después ocuparon ese mismo cargo don Gaspar de Mendoza (1581-1594) y don Melchor su hermano (1594-1608). Baltasar, el hijo mayor, nunca fue cacique-gobernador del altepetl. ${ }^{25}$

\section{Problemática en torno a la documentación temprana. Aplicación de un método analítico}

Lo que más llama la atención de la abundante información tardía en torno a la figura de don Diego es la imagen que de él se transmite, como la de un verdadero héroe cultural: se recalca su más noble ascendencia y se ensalza su papel como gran conquistador, rasgos que ofrecen la imagen de un poderoso señor. ${ }^{26}$ Un poder que en Mesoamérica se manifiesta, entre otras cosas, a través de la posesión de una vasta extensión de tierras. Pero, como ya se ha dicho, resulta extraño que aquellos cronistas que vivieron durante el tiempo que don Diego gobernó, como fue el caso de Tezozomoc

24 Chimalpahin: Ocho Relaciones... pág. 215. Según Tezozomoc (Crónica... pág. 173), la fecha de su muerte fue en 1557. Pero como dicen Pérez-Rocha, Emma, y Tena, Rafael: La nobleza indígena del centro de México después de la conquista, Instituto Nacional de Antropología e Historia, México, 2000, pág. 43, la fecha correcta debe ser 1562, pues si a 1549, fecha en la que inició su gobernación, le sumamos los 14 años que dice Tezozomoc que gobernó, nos situamos en 1562.

25 Sí lo mencionan los testigos de una probanza, pero con el inconveniente de que ésta es de mediados dell siglo XVII. Véase AGN, Tierras, 1593, n. ${ }^{\circ}$ 1, f. 13r, 14v, 10v, 25r, 27v, 29v, 37r. Don Baltasar también se llama asimismo gobernador en su propio testamento, supuestamente realizado en 1552. Algo completamente imposible porque por entonces gobernaba su padre en Tlatelolco. Además, al tratarse de un trasunto realizado en un papel grueso - similar al de los títulos primordiales de la sierra zapoteca- (comunicación personal de Michel Oudijk), me temo que este testamento se elaboró tardíamente, de acuerdo con ciertos intereses. Por lo mismo, no estoy de acuerdo con que 1552 sea una confusión de fechas, como asevera López ("El cacicazgo...”, pág. 235), tratando de dar una explicación a esta incongruencia histórica. El testamento, que está en nahuatl, fue traducido y transcrito por Rojas, Teresa et al.: Vidas y bienes olvidados, 5 vols., SEP/CONACULTA y CIESAS, México, 1999, vol. 2, págs. 96-98.

26 Véase también el caso de don Toribio Sandoval y San Martín Cortés de Cuernavaca, que fue convertido en un héroe cultural en el siglo XVIII, en Robert Haskett: Visions of Paradise: Primordial Titles and Mesoamerican History in Cuernavaca, University of Oklahoma Press, Norman, 2005, págs. 236-249. 
o el autor del Códice Aubin, ofrezcan una visión pobre de tan "ilustre" personaje. Fue precisamente ese aspecto el que determinó la necesidad de analizar las fuentes del siglo XVI, por un lado, y aquellas otras más tardías por el otro. Sólo de este modo se permitirá ver los cambios que se estaban produciendo en la sociedad, pero, sobre todo, entender qué estaba sucediendo con las fuentes que hoy nos sirven de estudio. Los documentos que aquí me interesa destacar son algunas cédulas reales y escudos de armas.

\section{La cédula de 1547 y 1525}

Un útil punto de partida para este análisis es retomar el asunto de los apellidos. Ya hemos dicho que mientras en las fuentes tempranas don Diego es conocido como don Diego de Mendoza (a veces con sus nombres indígenas), en las fuentes tardías aparece como don Diego de Mendoza Austria Moctezuma, lo cual debe tener una razón de ser. Ahora bien, la cuestión se complicó bastante al encontrar una cédula real del siglo XVI, firmada por don Antonio de Mendoza, donde el cacique tlatelolca aparecía ¡con todos su apellidos! Se trata de una cédula que el primer virrey firmó y fechó en 1547 y que lo que hace es reproducir otra de mayor antigüedad fechada en 1525 (fig. 3). ${ }^{27}$ Eso explica que aparezcan dos fechas distintas en lo que hoy es un solo documento:

Yo don Antonio de mendoça Visorey e Gover[nad]or por su mag[esta]d... por q[uan]to el rey mi señor fuere servido de despachar una su rreal çedula del thenor sig[uien]te $=\mathrm{El}$ rrey $=$ don hernando cortez $\mathrm{n}$ [uest]ro cap[ita]n general $\mathrm{e}$ gover[nad]or... sepades que por parte de don diego de mendoça austria y moctesuma caçique e prinçipal de esa çiudad de tenuxtitlan mex[i]co nos a çido hecha Relaçion diçiendo que se halla muy agraviado por la muerte tan violenta y afrentosa q[ue] le mandastis dar a su padre... E por ende vos mandamos que todas las tierras casas y haçiendas con todo lo demas de su señorio y cacicasgo se lo dareis y entregareis en n[uest]ro rreal nombre... en madrid a dos dias del mes de octubre de mill $e$ qui[nient]os e veinte y cinco a[ñ ]os/ yo el rrey... // E visto por mi la d[ic]ha çedula

27 La cédula de 1525 va desde donde dice "El rrey" y finaliza con "yo el rrey". No hay duda de que el documento es de 1547 porque así lo corrobora el tipo de letra, además de que la firma del virrey es auténtica. Se trata de algo que López ("El cacicazgo...", págs. 212-213) no entendió, de ahí su errónea conclusión. Ella simplemente creyó que el documento era de 1525. Entonces, como suele argumentar, dijo que 1525 fue un error de copia porque el virrey Mendoza no estaba en esa fecha en la Nueva España. Dedujo, así, que el documento debía remitirse a 1545, fecha de la Guerra de Mixtón en la que el virrey participó. Al parecer, la autora no observó que el documento terminaba con la fecha de 1547. 


\section{EL CASO DEL CACICAZGO TLATELOLCA}

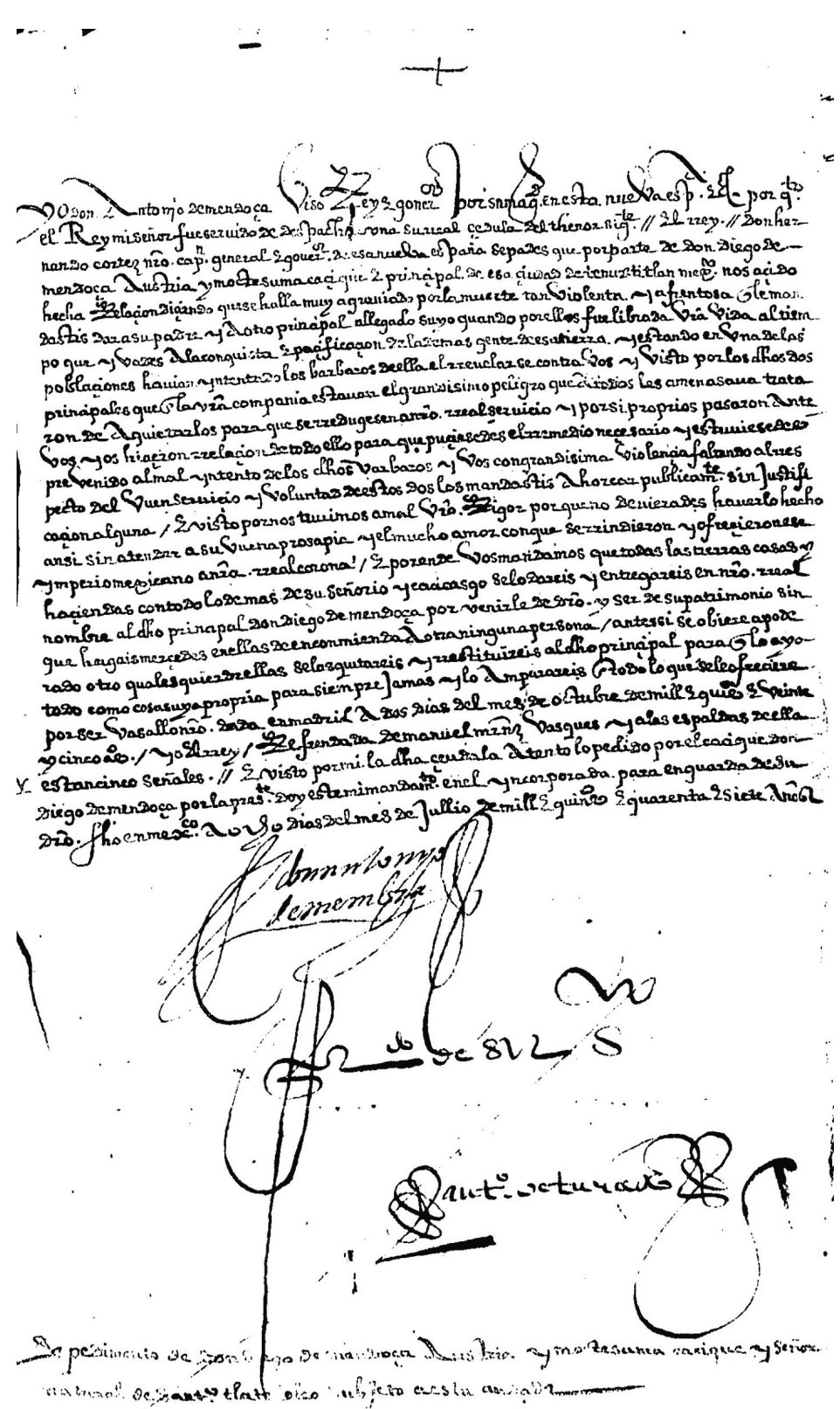

Fig. 3: Cédula de 1547 [1525]. Archivo General de la Nación, México. 
atento lo pedido por el cacique don diego de mendoça por la pres[en]te doy este mi mandam[en]to en el yncorporado para en guarda de su d[e]r[ech]o f[ec]ho en mex[i]co a ocho dias del mes de Jullio de mill e qui[nient]os e quarenta e siete años. [Firmado por don Antonio de Mendoza de puño y letra]. ${ }^{28}$

Los problemas con este documento son muchos. La primera cuestión sería cómo explicar que el gobernador apareciera en una fecha tan temprana (es decir, 1525) con todos sus apellidos (Mendoza Austria Moctezuma), cuando en más de una ocasión he reiterado que estos apellidos sólo se incluyen en fechas tardías. Asimismo habría que explicar por qué el rey decía en ella que don Diego era cacique y gobernador de Tenochtitlan y no de Tlatelolco. Es también raro que en el texto no se mencionara el nombre del padre de don Diego, pues las propiedades que el monarca le restituye en su carta están basadas en la importancia de ese padre. Al aludir a la violenta y afrentosa muerte que éste recibió en manos de Cortés, veladamente se da a entender que fue Cuauhtemoc. ${ }^{29}$ Por último, cómo saber cuáles eran las tierras que conformaban el señorío de don Diego si éstas no estaban mencionadas en el texto.

Si aceptamos que don Diego era hijo de Cuauhtemoc, y que éste era muy joven cuando murió por órdenes de Cortés, hay que presuponer que don Diego debía ser un niño de muy corta edad en 1525. Por tanto, es difícil imaginar que él mismo estuviera solicitando a Carlos I la restitución de las tierras de su cacicazgo. Por otro lado, es imposible que don Diego tuviera consigo todos los apellidos mencionados. Para 1525 el virrey Mendoza no había llegado aún a la Nueva España (lo haría en 1535), por lo que no es posible que éste ya le hubiera otorgado su apellido a la nobleza novohispana. Muy difícil de imaginar es también que dicha nobleza supiera ya que los Mendoza eran una de las familias más importantes y poderosas de la Baja Edad Media y, por tanto, deseara tener su apellido. Tampoco creo que el monarca otorgara el suyo porque ni siquiera se lo dio a Moctezuma, quien, no obstante, sí recibió el título de emperador. En cuanto al apellido Moctezuma, don Diego lo llevaría como supuesto hijo de Cuauhtemoc y de doña María.

Ante estas incongruencias, y a pesar de las reticencias iniciales, no pude más que llegar a la conclusión de que en cierto momento don Diego

28 AGN, Tierras, 1586, n. $^{\circ} 1$, f. 9 r.

29 Véase por ejemplo Anales de Tlatelolco..., págs. 31, 33, 35) o Tezozomoc: Crónica Mexicayotl..., págs. $165,172$. 
de Mendoza falsificó una cédula real: la de 1525. Sin embargo, no lo hizo en ese año porque entonces, como digo, debía de ser un niño de muy corta edad, por no decir que era imposible que la elite indígena tuviera ya los conocimientos suficientes como para elaborar un documento oficial español. Esto significa que la cédula de 1525 debió hacerse hacia 1547, cuando se puede constatar la presencia del primer virrey en la Nueva España. Una fecha en la que, además, la elite novohispana ya redacta documentos oficiales de diferente tipo y en la que la población local usualmente utilizaba apellidos españoles. ${ }^{30}$

Puede uno entonces imaginar que en 1547 don Diego se presentó ante el virrey Mendoza con una falsa cédula fechada en 1525. En sus elucubraciones quizás le interesó entonces decir que era principal de Tenochtitlan y no de Tlatelolco, algo por otra parte coherente si, como él decía, era nieto de Moctezuma e hijo de Cuauhtemoc, a quien Cortés había señalado como gobernante de Tenochtitlan. Sea como fuere, el virrey dio por buena la cédula de 1525 y la insertó en el documento que él mismo firmó en 1547. De esta manera, un documento falso adquiría el carácter de documento oficial, y por tanto quedó validado para el resto de sus días. De otra manera, no pueden explicarse las contradicciones arriba expuestas.

\section{La cédula y el escudo de armas del 8 de febrero de $1562^{31}$}

Según la cédula de concesión que acompaña al escudo de armas resguardado en el Archivo Ducal de Alba (fig. 4), este escudo se le concedió a don Diego de Mendoza como recompensa por su participación en la conquista y pacificación del Pano (¿Pánuco?), además de las rebeliones chichimecas en el camino de Zacatecas a la ciudad de México.

Don philippe etc por quanto por parte de vos don diego de mendoça cacique e governador del pueblo de axacuba que es en la nueva españa [...] que esta encomendado a ger[oni]mo lopez vezino y regidor de la ciudad de mexico me a sido hecha relaçion que vos y v[uest]ros pasados aver e sido y sois siempre governadores y prinçipales en el d[ic]ho pueblo [...] que fuisteis a la conquista e paçificacion de la provinçia de pano y despues os hallasteis en la jornada y allanamientos de las chichimecas que andavan alterados en el camyno que va desde la $\mathrm{d}[\mathrm{ic}]$ ha ciudad de mexico a las minas

30 Lockhart: Los nahuas después..., cap. IV. págs. 173-191.

31 Archivo Ducal de Alba (en adelante ADA), carpeta 238, n. ${ }^{\circ}$, doc. 45. 


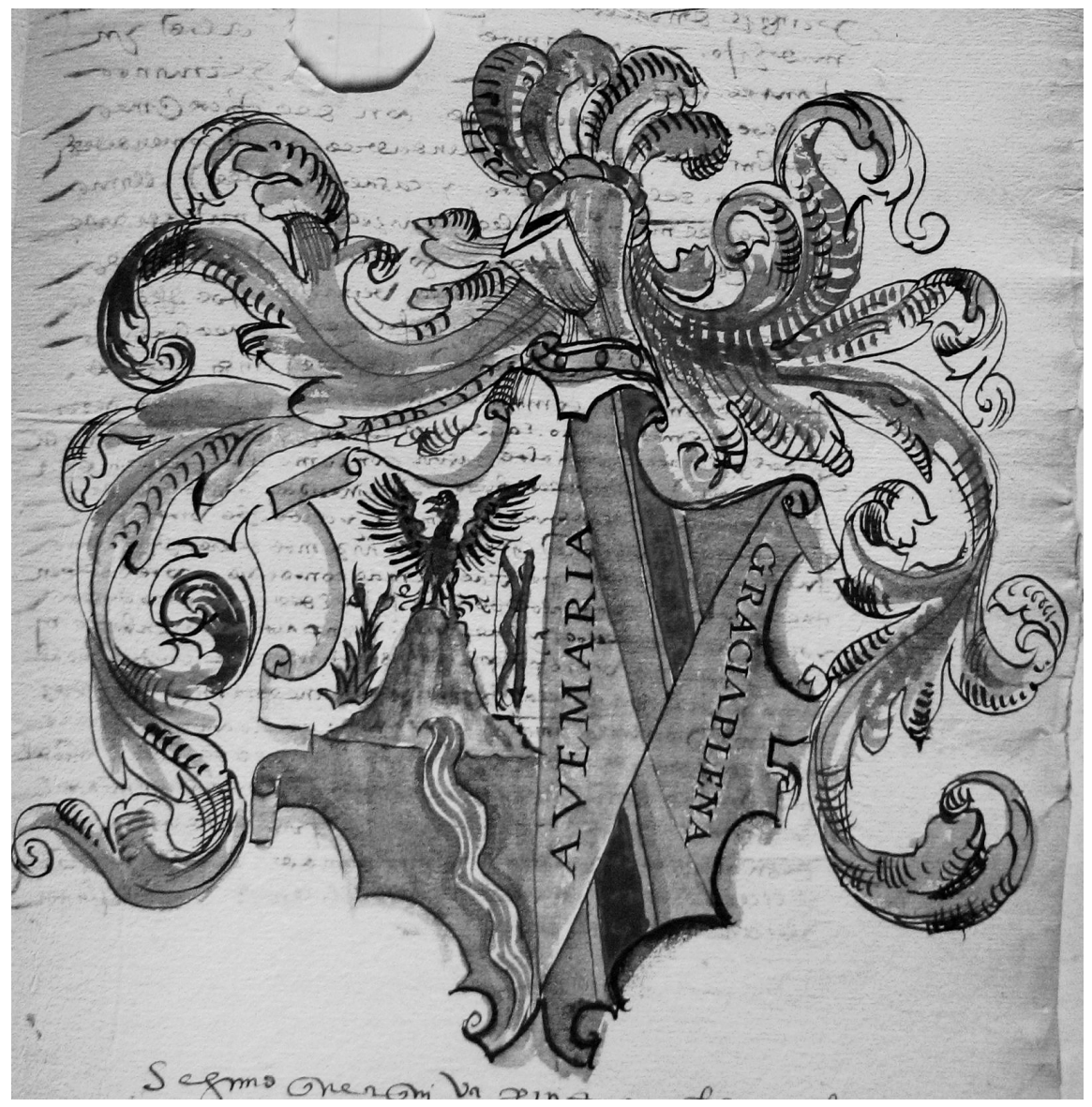

Fig. 4: Escudo de armas a don Diego de Mendoza de Axacuba (1562). Con permiso del Archivo Ducal de Alba. 
de las çacatecas siempre con v[uest]ras armas y cavallo [...] me fue suplicado que en remuneracion de los dhos v[uest]ros serviçios y de v[uest]ros antepasados y por que de vos y dellos quedase perpetua memoria y para mas obligar a n[uest]ro serviçio vos mandasemos dar por armas un escudo partido en dos partes [...]..$^{32}$

Aquí nos encontramos nuevamente con un problema fundamental. $\mathrm{Si}$ esta cédula se concedió el 8 de febrero de 1562, ello quiere decir que don Diego la recibió cuando ya estaba en la cárcel por el mencionado asunto de tierras. Pudiera entonces argumentarse que don Diego solicitara el escudo para contar con el respaldo real en los difíciles momentos por los que pasaba. Lo raro es que lo hiciera aduciendo que él y sus antepasados habían sido gobernadores de Axacuba y no de Tlatelolco, pueblo — este último - con mayor importancia que Axacuba.

Para justificar lo anterior sólo se me ocurre presuponer que Tlatelolco tuviera tierras en Axacuba, pero de momento no hay testimonio de ello. Sin embargo, de lo que sí tenemos testimonio es de la existencia de un cacique en Axacuba llamado don Diego de Mendoza, que nada tiene que ver con su homólogo de Tlatelolco. Esto, independientemente de que los tlatelolcas hubieran participado también en la conquista del norte de la Nueva España junto al virrey Mendoza, tal como se veía en el Códice de Tlatelolco ya comentado. Por tanto, se podría concluir con que el escudo de armas no iba digirido al cacique tlatelolca sino a uno de Axacuba del mismo nombre, que según documentos de este pueblo aún vivía en $1564 .{ }^{33}$ La implicación de esto es que en algún momento, alguien del cacicazgo tlatelolca se apropió de la cédula y el escudo otorgado al cacique de Axacuba, quedando ésta entre los papeles de don Diego o sus descendientes, quienes la copiaron reiteradas veces en el siglo XVIII. ${ }^{34}$

32 Ibidem, carpeta 238, n. $^{\circ} 2$, doc. 45, f. 1 r. La cursiva es mía.

33 Este gobernador murió hacia 1569. Véase, AGN, Tierras, 2354, n. o 1, f. 31v. López (“El cacicazgo...”, pág. 268) también había observado en el Códice Osuna la presencia de un alcalde del mismo nombre en el pueblo de Tetepango, muy próximo a Axacuba, que vivía en 1564. Descartó que fuera el cacique tlatelolca porque para entonces éste estaba muerto.

34 Una de las copias se halla en el AGN, Tierras, 1586, n. ${ }^{\circ}$ 1, f. 1r. Esta copia se reproduce a color en: Catálogo Documental, cultura y derechos de los pueblos indígenas de México, Secretaría de Gobernación y Archivo General de la Nación, México, 1997, págs. 99-100). En la obra de Villar Villamil, Ignacio: Cedulario Heráldico. Conquistadores de Nueva España, Talleres Gráficos del Museo Nacional de Arqueología, Historia y Etnografía, México, 1933, el escudo y la cédula llevan la numeración 130. La misma cédula está transcrita en Fernández de Recas: Cacicazgos y nobiliario..., págs. 276277, mientras que el escudo está en esta misma obra en la ilustración núm. 1. La segunda copia se encuentra en la Biblioteca Nacional de Antropología e Historia, Archivo Histórico, Colección Antigua, 223, f. 132 r. 
El escudo que comentamos está dividido en dos cuarteles. En el primero se representa un cerro del que mana agua, elementos (el cerro-agua) que en la iconografía mesoamericana aluden al concepto altepetl, o lo que los españoles vieron como equivalente a pueblo. Ahora bien, para proporcionar el nombre del pueblo en cuestión, la pictografía solía colocar un elemento fonético sobre el cerro o en su interior. No obstante, nada de eso se dibujó. El inconveniente es que la imagen sólo deja ver dicho cerro con un águila negra sobre su cima, cuya lectura nunca nos proporcionaría el nombre del pueblo, probablemente uno de los que don Diego gobernaba (sea Axacuba, sea Tlatelolco). A ambos lados, un mezquite, el arco y la flecha, elementos asociados con el paisaje y medio de vida de los chichimecas del norte, donde sí se desarrollaba la vida de la gente de Axacuba. ${ }^{35}$

El segundo cuartel está dividido por bandas azules y rojas que se cruzan diagonalmente e incluyen el saludo "ave María gracia plena". Esta imagen no es otra que la del blasón del linaje de los Mendoza, lo cual podría ser sinónimo de la máxima muestra de agradecimiento por parte del virrey al gobernador de Axacuba por su colaboración en la conquista.

\section{La cédula y el escudo de armas del 16 de agosto de $1563^{36}$}

Entre los papeles del cacicazgo tlatelolca hay dos copias tardías de otro escudo de armas, ambas elaboradas en el siglo XVIII. ${ }^{37}$ Los trasuntos de las cédulas de concesión mencionan que en este caso el escudo se le concedió a don Diego de Mendoza por su participación y la de su padre en la conquista y pacificación de México, Jalisco y las chichimecas. Esta información en sí no sería un problema si no es porque resultara difícil imaginar a don Diego - por entonces un niño de muy corta edad-, participando en la conquista junto a Cuauhtemoc, a sabiendas de que Cuauhtemoc nunca estuvo en esas conquistas sino que, por el contrario, se adentró con

35 Es decir, elementos asociados con valores en torno a la caza, pero también a la guerra. La proliferación de elementos de guerra como escudos, macanas, pedernales ensangrentados, etc. son una constante en los blasones solicitados al rey. Véase Castañeda de la Paz y Luque Talaván: “Conquistadores o conquistados...” (en prensa) y Castañeda de la Paz: “Central Mexican...” (en prensa).

36 ADA, Carpeta 238, n. ${ }^{\circ}$ 2, doc. 57. Este escudo está reproducido en una imagen a color de muy buena calidad, con un comentario, en Luque Talaván y Castañeda de la Paz: "Escudos tlaxcaltecas. Iconografía...".

37 Véase en el AGN, Tierras, 1593, n. ${ }^{\circ}$ 1, f. 1r, y en la BNAH, AH, Colección Antigua. doc. 223, f. 123 r. 
Cortés hacia Guatemala. Por otro lado, cómo explicar la presencia del blasón de los Ponce de León en uno de los cuarteles del escudo. Es conveniente entonces una breve descripción del mismo.

A diferencia del escudo anterior, éste aparece dividido en cuatro cuarteles (fig. 5). El primero está a su vez dividido en dos secciones: una de ellas contiene un escudo o chimalli con una decoración muy estilizada; una espada de la que sólo se alcanza a distinguir la empuñadura; una bandera blanca; la cabeza de un animal (quizás un coyote) y detrás de él unos cactle o sandalias. Todos estos elementos posiblemente hagan alusión a las armas con las que el conquistador indígena fue a la batalla. ${ }^{38}$ En la segunda sección del primer cuartel se dibuja un castillo sobre aguas azules, elementos que simbolizan a la ciudad de Tenochtitlan. Respecto al segundo cuartel, éste representa unas barras amarillas y rojas de las que desconozco su simbología. El tercer cuartel contiene un águila coronada con las alas extendidas, la cual se posa sobre una peña con plantas a ambos lados. Finalmente, el cuarto cuartel es el que incorpora el blasón de los Ponce de León en España, representado por un león rampante, dos barras amarillas y tres rojas, todo ello enmarcado por ocho escudetes alrededor.

Para resolver las interrogantes arriba planteadas, fue importante el hallazgo del original de esta cédula y su escudo. Como en el caso anterior, éste se encontraba en el Archivo Ducal de Alba y no hay duda de que es del siglo XVI. Se trató de un hallazgo vital para la investigación porque a través de ese material hoy se puede confirmar que el presente escudo no le fue concedido a don Diego de Mendoza sino a don Lucas Ponce de León, hijo de un tlaoani tlaxcalteca, por su participación y la de su padre en la conquista y pacificación de la ciudad de México, las provincias de Jalisco y las Chichimecas.

A día de hoy no me ha sido posible identificar la figura de este principal de Tlaxcala que probablemente tomó el apellido del adelantado Juan Ponce de León. Empero, ahora cobra sentido que el escudo incorpore el blasón de los Ponce de León y la representación de Tenochtitlan. Hay que recordar que fueron los tlaxcaltecas los que participaron en la conquista de

38 En el ADA tenemos precedentes de estos elementos. Concretamente en el escudo de don Jerónimo del Águila, principal del Cabildo de Tlacopan (hoy Tacuba), quien en la solicitud de su escudo pide al rey que se incorpore el dibujo de las armas con las que participó en la conquista y con las que destruyó templos y dioses. Véase Castañeda de la Paz, y Luque-Talaván “¿Conquistadores o conquistados..." (en prensa) para un análisis iconográfico del blasón. Pérez-Rocha y Tena (La nobleza indígena... pág. 288) transcriben la carta de solicitud de don Jerónimo al rey. 


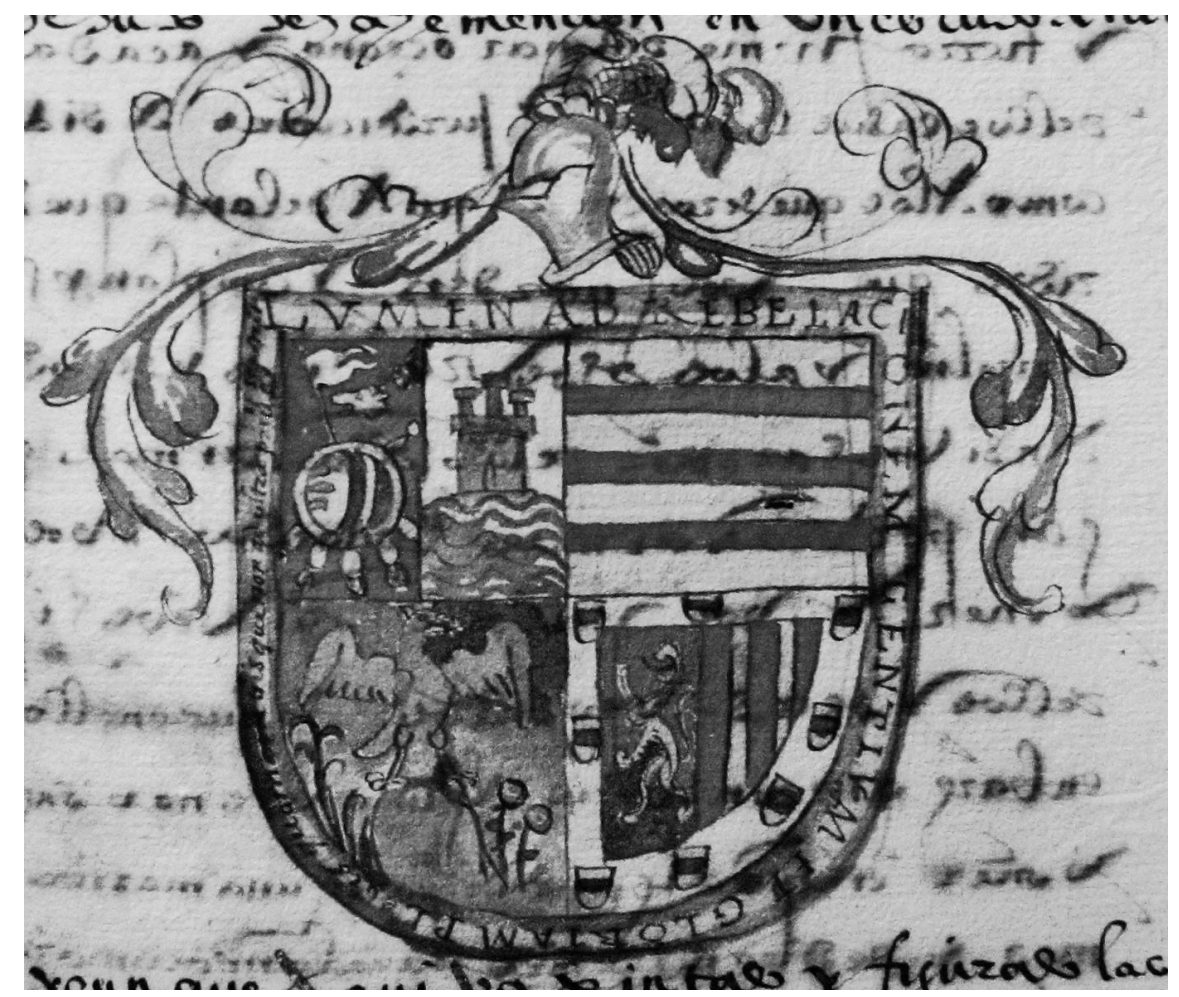

Fig. 5: Escudo de armas a don Lucas Ponce de León de Tlaxcala (1563). Con permiso del Archivo Ducal de Alba. 
la isla de México donde estaba asentada la ciudad, de ahí que don Lucas incorporara la imagen de la ciudad derrotada en su escudo. Hubiera resultado contradictorio que lo hubiera hecho un tlatelolca (o sea, don Diego de Mendoza), cuando ya se ha dicho que, una vez derrotada Tenochtitlan, Cuauhtemoc se refugió en Tlatelolco para resistir el asedio español, siendo apoyado por tenochcas y tlatelolcas.

Por tanto, este ejemplo viene a demostrar nuevamente cómo en algún momento los thatelolcas accedieron a este escudo, el cual se apropiaron y copiaron en el siglo XVIII. Es exactamente lo mismo que hicieron con el escudo de aquel otro don Diego, cacique de Axacuba.

\section{La documentación más tardía. Una posible respuesta a tantas contradicciones}

Además de las cédulas arriba analizadas, existen otras cédulas que, a pesar de tener fechas muy tempranas, son trasuntos redactados en el XVIII. No tenerlo presente ha sido motivo de largos años de quebraderos de cabeza para los investigadores ( $\mathrm{e}$ incluso para la audiencia!) que no pueden explicar las incongruencias de su contenido y, a veces, lo temprano de su fecha. Es el caso de la cédula real firmada en Sevilla el 14 de abril de 1523, cuyo original no se ha encontrado y lo único que tenemos de ella son copias del siglo XVIII, donde se reitera que la original era de 1523. En este apartado se analizarán dos cédulas fundamentales para entender qué está pasando con este tipo de documentación objeto de nuestro estudio.

\section{Otra cédula del 16 de agosto de 1563 en el Archivo General de la Nación ${ }^{39}$}

Al inicio sorprendió hallar una cédula con la mismísima fecha que la del Archivo Ducal de Alba ya analizada, si bien un análisis de su contenido permitió observar que, aunque eran muy similares, no eran idénticas. Este descubrimiento, y el hecho de que la del Archivo General de la Nación sea un trasunto de una cédula del siglo XVI, me llevó a la conclusión de que para la redacción de la del Archivo General de la Nación, el copista se

39 AGN, Tierras 1593, n. ${ }^{\circ} 1$, f. 6v-8r. 
basó en la del Archivo Ducal de Alba. El punto más fuerte que corroboraba mi hipótesis es que el documento del Archivo General de la Nación también terminaba con la concesión de un escudo de armas. No fue casualidad que este escudo fuera el de don Lucas Ponce de León, dividido en cuatro cuarteles, y que ya se ha descrito.

Por tanto, como las dos cédulas del 16 de agosto de 1563 son tan similares, no me detendré a analizar toda la información de cada uno de sus párrafos. Aquí sólo comentaré aquellos puntos que sean muy importantes para la investigación. Vayamos por partes:

- La cédula del Archivo General de la Nación contempla los nombres casi completos del cacique tlatelolca: Don Diego de Mendoza Austria. Por alguna razón ignora el Moctezuma. Lógicamente, ni el nombre ni los apellidos de don Diego aparecen en la cédula del Archivo Ducal de Alba porque ésta era para don Lucas Ponce de León.

- Ahora se menciona el nombre del padre de don Diego: Fernando Cuauhtemoc Guichiliguil (Huizilihuitl). El nombre Huitzilihuitl parece provenir de una mala lectura del glifo de este personaje: originalmente un águila (cuauh-tli) descendiendo (temo-a) y que en la documentación tardía es un simple pajarito que está parado, el cual parece que se confundió con un colibrí (Huitzilihuitl). Por tanto, la oculta identidad del padre de don Diego que se observa en la cédula de 1525 [1547] queda ya aquí desenmascarada.

- Se hace alusión al abuelo de don Diego, aclarándose que se trata del monarca y emperador Moctezuma II y, sorprendentemente, empieza a difundirse la idea de que el origen del imperio de Moctezuma II y el de Cuacuauhpitzahuac (primer señor de Tlatelolco), venía de Tezozomoc de Azcapotzalco. Una idea que queda asimismo plasmada en el ya comentado Códice Techialoyan García Granados. En ese documento dibuja la llamada rueda de la tepanecayotl que no viene más que a representar a los gobernantes tepanecas del área. Lo interesante es ver cómo a continuación de esa escena se pinta un gigantesco nopal con los linajes de Tenochtitlan y Tlatelolco, representados a través de sus respectivos señores entre sus pencas. La idea era la misma: expresar que ambos pueblos tenían sus raíces en los tepanecas.

Una idea que también se registraba en un documento alfabético de 1741 del que arriba ofrecía un extracto: el Árbol de la Cesárea Regia Prosapia. Por tanto, estudiar y comparar el conjunto de las fuentes del cacicazgo fue lo que me permitió afirmar que todo esto era producto de una ree- 
laboración histórica tardía y que el trasunto de la cédula original del siglo XVI se hizo en el siglo XVIII. De hecho, no es una casualidad que la cédula de 1563 del Archivo General de la Nación se hiciera en la misma fecha que el Árbol ... arriba citado. O sea, en 1741.

- A continuación, siguiendo la fórmula de este tipo de cédulas de concesión, hay un reconocimiento al servicio de don Diego y su padre como leales vasallos en las conquistas. Esto se hace también en la cédula del Archivo Ducal de Alba antes de pasar a mencionar esas conquistas. En ambos documentos son las mismas: "la ciudad de essa nueva españa", Xochipila, Meztitlan y Xalisco. Además, y con toda razón, se alude al amor y amistad con que don Diego y su padre sirvieron a Hernán Cortés y no ya al virrey Mendoza, puesto que hay que recordar que la cédula original se otorgó al tlaxcalteca don Lucas Ponce de León, personaje que sí acompañó a Cortés (y no al virrey) en la conquista de Tenochtitlan. En relación con esto está la llamada de atención en cursiva cuando se han citado los pueblos conquistados. Hay que pensar que como el documento estaba ahora en manos de los tlatelolcas, éstos se vieron obligados a tergiversar una información incómoda. Por ello, lo que debería de ser la "conquista y pacificación de la ciudad de México" pasó a convertirse en la "conquista y pacificación de la ciudad de esa nueva españa".

- Lo último que registra esta cédula es la concesión del escudo de armas de don Lucas Ponce de León.

\section{La cédula real del 14 de abril $1523^{40}$}

Entre las cédulas concedidas a don Diego de Mendoza figura una muy controvertida por la fecha de su emisión: en Sevilla, el 14 de abril de 1523. La discusión académica ha girado principalmente en torno a lo temprano de la fecha de una cédula en la que se reconoce la labor del cacique tlatelolca junto al virrey Mendoza en la conquista de los territorios del norte de la Nueva España. Como ya se ha dicho, este gobernante no estuvo en la Nueva España en esos años, ni esas conquistas tuvieron lugar en una fecha tan temprana. Esto, por no decir que don Diego era un niño de muy corta edad en ese año. Para explicar estas contradicciones, los investigadores

40 Existen varias copias de esta cédula en AGN, Tierras 1586, n. ${ }^{\circ}$ 1, f. 1v-5r; Tierras 2692, $2 \mathrm{a}$. parte, n. ${ }^{\circ} .10$ [n. $\left.{ }^{\circ} 40\right]$, f. $5 \mathrm{v}-9$ r; Vínculos, 80 , n. ${ }^{\circ} 5$, f. $3 \mathrm{v}-4 \mathrm{v}$. 
generalmente han aducido que la cédula es una falsificación o bien argumentan errores de copiado en el momento de escribir la fecha. ${ }^{41}$ Un análisis del contenido de este documento demostrará qué está pasando con él.

Inicialmente hay que observar que la primera parte del contenido de la cédula es idéntica a la del 16 de agosto de 1563 del Archivo General de la Nación. Es decir, aquella relativa al Árbol de la Cesárea Regia Prosapia, si bien don Diego aparece ya con todos sus apellidos (Mendoza Austria Moctezuma) y su padre, don Fernando Cortés Cuauhtemoc, sin el Huitzilihuitl. Siguiendo el contenido de dicha cédula se vuelve a indicar que el abuelo de don Diego es Moctezuma Xocoyotzin y que el origen del imperio mexicano está en Tezozomoc de Azcapotzalco. Lo mismo en cuanto a la empresa de padre e hijo en las conquistas del norte de la Nueva España, conquistando y pacificando "la ciudad de esa Nueva España" (o sea, Tenochtitlan), Xochipila, Meztitlan y Jalisco. Sin embargo, a partir de aquí la cédula de 1523 va a añadir que ambos sujetaron y pacificaron también Zacatecas, San Luis, Axacuba y las provincias de toda la Teotlalpan.

Después se retoma el modelo de la cédula de 1563 del Archivo General de la Nación y por tanto se menciona el vasallaje y amparo a "Fernando" Cortés y, por consiguiente, la concesión del escudo de armas de don Lucas Ponce de León. Un escudo de armas que ya no aparece fechado el 16 de agosto de 1563 sino el 14 de abril de 1523. En mi opinión, para otorgarle una mayor antiguiedad a los papeles.

Ahora bien, mientras todas las cédulas de concesión analizadas terminan con la descripción del escudo de armas, la de 1523 va a tomar y seguir el modelo de la cédula de 1525 [1547] para hablar del cacicazgo de don Diego. Pero mientras que ya vimos que en esa temprana cédula no se decía cuáles eran las tierras de ese cacicazgo, en la de 1523 éstas se van a especificar con todo detalle. Se pasa entonces a citar el Rincón de Tenayuca, Ticuman y Cuauhtepec (lugares que conforman el llamado Rincón de don Diego), además de todos los cerros, llanos y ríos que regaban esas tierras. Es además parte de dicho cacicazgo la laguna de San Cristóbal Ehecatepec, las provincias de la Teotlalpan, Meztitlan, Xochipila Jalisco, Chalco Atengo, Costocan y Temamatlailas (?), así como las tierras de Tepopula, Tlayacapan, Camacoyo (?) y todas las de Chilapa. Por último, la cédula expresaba el deseo real de que don Diego y sus descendien-

41 Barlow (Tlatelolco. Fuentes e..., pág. 148) trae a colación la posible falsedad de la cédula mientras que López ("El cacicazgo de...", págs. 215, 219) no deja de insistir en los errores de fechas en los documentos. 
tes fuesen los gobernadores de Santiago Tlaltilulco, Axacuba y Chilapa de forma perpetua.

Por supuesto, resulta contradictorio que la cédula de 1523 sea la más antigua y la más elaborada. Como aquí se ha demostrado, esta cédula es producto de una reelaboración basada en otras fuentes documentales. Por lo mismo, no hablaría yo de un error de copia en su fechamiento. Tampoco lo haría porque el territorio citado es inmenso, siendo prácticamente imposible creer que don Diego fuera reconocido señor de tan vastas posesiones. Algo de lo que ni siquiera gozaron los descendientes de Moctezuma Xocoyotzin. ${ }^{42} \mathrm{La}$ fecha parece responder más bien al deseo de ciertas familias de otorgarles una pátina de más antigüedad a su pasado histórico. Con ello no estoy negando la inexistencia de errores de copiado. Un ejemplo de que estos errores sí existieron lo tenemos cuando los caciques de Tlacopan o Tacuba copiaron el escudo de don Lucas Ponce de León y le pusieron la fecha del 17 de agosto de 1563 en vez de la del 16 de agosto de ese mismo año. Sin embargo, no creo que fuera un error que los de Tetepango (Estado de Hidalgo), al copiar la misma cédula, pusieran la fecha del ¡14 de abril de $1523 !^{43}$ Estos dos ejemplos sólo vienen a demostrar que hay una intención a la hora de copiar documentos y fecharlos. Otro asunto es saber por qué y de dónde tomaron los tlatelolcas esa fecha del 14 de abril de 1523.

\section{Conclusiones}

El presente trabajo es una muestra de las dificultades que puede hallar el investigador a la hora de trabajar con la documentación de un cacicazgo de larga vida. Los ejemplos que aquí se han mostrado no hacen más que advertirnos que es fundamental separar la información que aportan los

42 López ("El cacicazgo de...”, pág. 215) ve indudable el parentesco de don Diego con la familia Moctezuma basándose en que las autoridades coloniales no tuvieron problema para reconocerlo como un Moctezuma y porque precisamente gracias a ese parentesco la Corona le otorgó muchas tierras como parte de su cacicazgo. Sin embargo, no puedo estar de acuerdo con este argumento. Como en este trabajo se viene a demostrar, para entender las fuentes legadas por los caciques tlatelolcas era necesario un análisis filológico. Sólo así se puede comprender la gran alteración que sufrió la documentación producto de las reelaboraciones históricas.

43 Los documentos de Tacuba y Tetepango se hallan en el AGN, Vínculos 74, n. ${ }^{\circ}$ 1, f. 30r-33r y Tierras, 2692, 2a. parte, n. ${ }^{\circ} 10$ [n. $\left.{ }^{\circ} 40\right]$, f. 5v-9r respectivamente. Por lo mismo, tampoco es un error que la cédula de concesión del ADA, Carpeta 238, n. ${ }^{\circ}$ 2, doc. 45, f. 1r diga que Jerónimo López tenía encomendado el pueblo de Axacuba y los de Tacuba sustituyan el Axacuba por Tacuba como se ve en otro documento del AGN, Vínculos, 74, n. ${ }^{\circ}$ 1, f. 33r. 
documentos del siglo XVI de aquella dada por documentos más tardíos, con la finalidad de ir comparándola después. Todo ello teniendo también muy en consideración que el trasunto de un documento del siglo XVI no necesariamente recoge información estrictamente de esa centuria. El ejemplo de ello queda reflejado en las cédulas del 16 de agosto de 1563 (la del Archivo General de la Nación y no la del Archivo Ducal de Alba) y la del 14 de abril de 1523, que aquí se han analizado. Por tanto, no emplear un método crítico de las fuentes objeto de estudio puede hacernos errar en nuestras interpretaciones. Y esto es algo que hasta ahora no se había hecho al estudiar el cacicazgo de los Mendoza Austria Moctezuma. Como se demuestra, en este caso tenemos muchos documentos y sus correspondientes traslados, haciendo posible este análisis filológico. Sin embargo, cuando sólamente tenemos los traslados de los siglos XVII o XVIII, tenemos que tener también presente la posible existencia de este proceso.

Es muy probable que don Diego fuera ya el artífice de elaborar nuevos documentos. Me refiero a la cédula de 1525, la cual el virrey dio por buena e insertó en un documento firmado de su puño y letra en 1547. Este tipo de situaciones es importante tenerlo presente porque de esa manera el virrey Mendoza dio validez legal a un documento que parece ser la semilla del engrandecimiento de don Diego. El objetivo del mismo era la restitución de las tierras del cacicazgo del citado cacique, teniendo como base de sus reclamaciones la afrentosa muerte que sufrió su padre a manos de Hernán Cortés.

Es difícil saber quién o quiénes - y cuándo- se apropiaron en Tlatelolco de las tempranas cédulas otorgadas a don Diego de Axacuba y a don Lucas de Tlaxcala. Unas cédulas que sólo se limitaban a conceder un escudo de armas como compensación por los servicios de conquista de los mencionados caciques. No obstante, lo más importante de todas estas cédulas es ver cómo cada una sirvió para reelaborar otras más tardías. Como aquí se ha demostrado, la cédula del 16 de agosto de 1563 de Archivo Ducal de Alba fue trasuntada en 1741, pero el autor de ese trasunto no se limitó a copiarla fielmente sino que se tomó la libertad de encabezarla con la información de otro documento también elaborado en 1741 y ya citado: el Árbol de la Cesárea Regia Prosapia. Ahora bien, el culmen de la reelaboración llega con la cédula del 14 de abril de 1523, la cual, como se ha visto en detalle, se redactó a partir de la anterior. A pesar de ello, su contenido es aún más elaborado y por tanto contiene mayor información. No sólo se citan todas las tierras del cacicazgo de don Diego (en este caso 
siguiendo la estructura de aquella cédula de 1525 [1547]) sino que se nombra a don Diego y sus descendientes como caciques perpetuos de varios lugares. Por tanto, la cédula de 1523 es la más elaborada porque seguramente es la que se trasuntó más tardíamente. Esto último explica que de otorgar un simple escudo de armas en el siglo XVI, el rey pasara supuestamente a citar una vasta región de tierras como parte del cacicazgo.

La implicación de todo esto es que la información del siglo XVI, contenida en los trasuntos realizados en el siglo XVIII, no puede valorarse como si se tratara de información exclusivamente del siglo XVI porque la documentación se reelabora incorporando información de distintas épocas y eso explica la existencia de muchas incongruencias históricas.

Por otro lado, como aquí se ha demostrado, tampoco es conveniente que los historiadores, ante la imposibilidad de explicar esas incongruencias históricas, concluyan que los escribanos cometieron errores a la hora de copiar las fechas. En mi opinión, hay una intencionalidad de otorgarle mayor antigüedad a sus respectivos papeles. Y como ya dije, otro asunto sería averiguar de donde tomaron o por qué seleccionaron ese día y ese año para fechar un documento. Algo a lo que hasta ahora no he podido dar una respuesta.

Para finalizar, cabría preguntarse entonces si don Diego fue el gran cacique que nos pintan las fuentes tardías o no. Yo no lo creo. Es raro que ni Tezozomoc ni otros cronistas hablen de él en el siglo XVI. Más bien creo que fue él mismo el que comenzó a fraguar su imagen. El que sembró la semilla que floreció en el siglo XVIII y de la que se agarraron varios de sus descendientes. Se formó así un pasado colonial, probablemente reelaborando la información de varias fuentes pictográficas, cédulas reales y aquella información que todavía permanecía en la memoria. Esto tuvo como resultado que don Diego se convirtiera en un cacique con los apellidos más nobles de una época, al que se le hacía poseedor de un gran imperio que seguramente nunca tuvo. El objetivo debió ser la obtención de ciertas prerrogativas reales dada la situación de una nobleza indígena ya muy debilitada en el período colonial tardío. 